\title{
Serum zinc levels in corticosteroid-treated asthmatic patients
}

\author{
R. ELLUL-MiCALlEF \\ M.D., Ph.D.(Edin) \\ A. Galdes \\ M.Sc. \\ F. F. FENECH * \\ M.D., F.R.C.P.(Lond), F.R.C.P.(Edin) \\ Department of Physiology and Biochemistry and * Department of Medicine, Royal University of Malta
}

\begin{abstract}
Summary
Serum zinc levels have been measured in twenty-four asthmatic patients, of whom sixteen were on long term corticosteroid therapy. They were carefully screened to exclude any concomitant disease. The nonsteroid-treated asthmatics had normal serum zinc levels which ranged from 89 to $138 \mu \mathrm{g} / \mathrm{ml}$. The corticosteroid-treated patients had a mean serum zinc level of $64 \pm 9 \mu \mathrm{g} / 100 \mathrm{ml}$; this was significantly lower than normal $(P=<0.001)$.
\end{abstract}

\section{Introduction}

It was suspected that zinc was an essential nutrient for living organisms when Raulin (1869) showed it to be necessary for the growth of Aspergillus niger, but it was over 50 years later that it was conclusively proved that zinc is necessary for the normal development of animals (Bertrand and Bhattacherjée, 1934). Raoult and Breton (1877) were the first to report its presence in the human liver. The detection of zinc in the metallo-enzyme carbonic anhydrase, identified and purified from bovine erythrocytes (Keilin and Mann, 1940) prompted a tentative explanation of the action of this metal.

Because of difficulties in methodology, investigations were for a long time limited to a purely qualitative nature. It is only comparatively recently that simple, accurate and sensitive methods have become available (Willis, 1962). Zinc levels have now been measured in a number of clinical conditions and found to be decreased (Halsted and Smith, 1970; Oon et al., 1974; Barbeau and Donaldson, 1974). Flynn and his associates $(1971 \mathrm{a} ; 1973)$ have shown that corticosteroids lower circulating zinc levels whilst other workers have reported finding no such effect (Briggs, Briggs and Austin, 1971). The present study has been carried out to determine whether long-term corticosteroid therapy has any effect on

Correspondence: Dr R. Ellul-Micallef, Department of Physiology, Royal University of Malta. the serum zinc levels of patients with chronic bronchial asthma.

\section{Patients and methods}

Twenty-four patients were chosen from the Asthma Clinic, St Luke's Hospital, Malta, after informed ${ }^{-}$ consent had been obtained. All had been previouslys diagnosed as suffering from chronic bronchialo asthma. The duration of their disease ranged between 8 and 32 years. None had any other concomitaq $t$ disease, in particular, chronic respiratory infection. Corticosteroids had been given to fifteen of them a number of years and to a sixteenth for a period of 3 months. They were still taking the drugs when blood samples were taken. Seven other patients hado never had corticosteroid therapy and one (No. 17) $\mathbb{Q}$ had had a short course of prednisolone therapy $2 \overrightarrow{\overrightarrow{0}}$ years previously and has been included with the non-5 corticosteroid-treated patients. Table 1 shows the clinical and therapeutic data of the corticosteroid treated patients.

Venous blood was collected with minimal venostasis in disposable plastic syringes. Blood waso allowed to clot and centrifuged at 1500 r.p.m. within an hour of its being withdrawn. Serum specimens ino which haemolysis occurred were discarded. Serum zinc concentration was determined after the proteinso were precipitated with $10 \%$ trichloroacetic acid (Davies, Musa and Dormandy, 1968) and removed을. by centrifugation, using a Unicam S.P. 90A atomic absorption spectrophotometer with an air-acetylene flame. Standard curves were obtained using a N standard zinc solution $(1 \mathrm{mg} / \mathrm{ml})$ Analar diluted with deionized water. The standards were made in a $\mathrm{NaClo}$ solution as it has been reported that sodium reduceso absorbance readings for zinc (Prasad, Oberleas and Halsted, 1966). Reagent blanks were unrecordable $\stackrel{\mathscr{S}}{+}$ Total plasma protein and plasma albumin concen- 0 trations were measured in all patients. All computations were performed on a Hewlett-Packard $9100 \mathrm{~B}$ 
TABLE 1. Clinical and therapeutic data of the corticosteroidtreated patients

\begin{tabular}{cccccc}
\hline $\begin{array}{c}\text { Patient } \\
\text { no. }\end{array}$ & $\begin{array}{c}\text { Age } \\
\text { (years) }\end{array}$ & Sex & $\begin{array}{c}\text { Duration } \\
\text { of } \\
\text { disease } \\
\text { (years) }\end{array}$ & $\begin{array}{c}\text { Present } \\
\text { dose of } \\
\text { prednisolone } \\
\text { (mg/week) }\end{array}$ & $\begin{array}{c}\text { Duration } \\
\text { of therapy } \\
\text { (years) }\end{array}$ \\
\hline 1 & 65 & M & 20 & $52 \cdot 5$ & 6 \\
2 & 44 & M & 8 & $52 \cdot 5$ & 4 \\
3 & 58 & F & 10 & 30 & 2 \\
4 & 56 & F & 32 & 35 & 6 \\
5 & 30 & M & 15 & 35 & 4 \\
6 & 68 & F & 12 & $61 \cdot 25$ & $2 \cdot 5$ \\
7 & 36 & F & 18 & 30 & $1 \cdot 5$ \\
8 & 48 & M & 17 & $52 \cdot 5$ & 3 \\
9 & 52 & M & 16 & $43 \cdot 75$ & $2 \cdot 5$ \\
10 & 72 & M & 22 & $52 \cdot 5$ & 4 \\
11 & 66 & F & 9 & 70 & $0 \cdot 75$ \\
12 & 39 & F & 14 & 35 & $1 \cdot 5$ \\
13 & 47 & M & 25 & 70 & 1 \\
14 & 53 & M & 13 & $22 \cdot 5$ & $3 \cdot 5$ \\
15 & 65 & F & 28 & 35 & 4 \\
16 & 39 & F & 15 & $52 \cdot 5$ & $0 \cdot 25$ \\
\hline
\end{tabular}

Calculator fitted with a 9101A Extended Memory and a 9125B Plotter.

\section{Results}

The serum zinc values of the bronchial asthmatic patients receiving corticosteroid therapy ranged between 52 and $81 \mu \mathrm{g} / 100 \mathrm{ml}$. The mean \pm 1 s.d. for these patients is $64 \pm 9 \mu \mathrm{g} / 100 \mathrm{ml}$, as shown in Table 2 and Fig. 1. The mean serum zinc level in the corticosteroid-treated patients is significantly lower than in those who were not given corticosteroids $(t=8.52 ; P=<0.001)$. The corresponding values for the asthmatic patients whose treatment did not include corticosteroids are $110 \pm 18 \mu \mathrm{g} / 100 \mathrm{ml}$. These fall well within the normal range of values of our laboratory. Total plasma protein concentrations and, in particular, plasma albumin concentrations of all the patients studied were in the normal range.

\section{Discussion}

Flynn and his co-workers (1971a) were the first to report a fall in serum zinc levels in three patients

TABLE 2. Serum zinc levels $(\mu \mathrm{g} / 100 \mathrm{ml})$

\begin{tabular}{lcccc}
\hline & $\begin{array}{c}\text { Patient } \\
\text { no. }\end{array}$ & $\begin{array}{c}\text { Serum } \\
\text { Zn }\end{array}$ & $\begin{array}{c}\text { Patient } \\
\text { no. }\end{array}$ & $\begin{array}{c}\text { Serum } \\
\text { Zn }\end{array}$ \\
\hline (a) Corticosteroid- & 1 & 54 & 9 & 64 \\
treated & 2 & 57 & 10 & 62 \\
asthmatics & 3 & 69 & 11 & 81 \\
& 4 & 52 & 12 & 67 \\
& 5 & 56 & 13 & 68 \\
& 6 & 63 & 14 & 58 \\
& 7 & 77 & 15 & 57 \\
(b) Non-steroid- & 17 & 61 & 16 & 78 \\
treated & 18 & 138 & 21 & 97 \\
asthmatics & 19 & 89 & 23 & 110 \\
& 20 & 109 & 24 & 127 \\
\hline
\end{tabular}

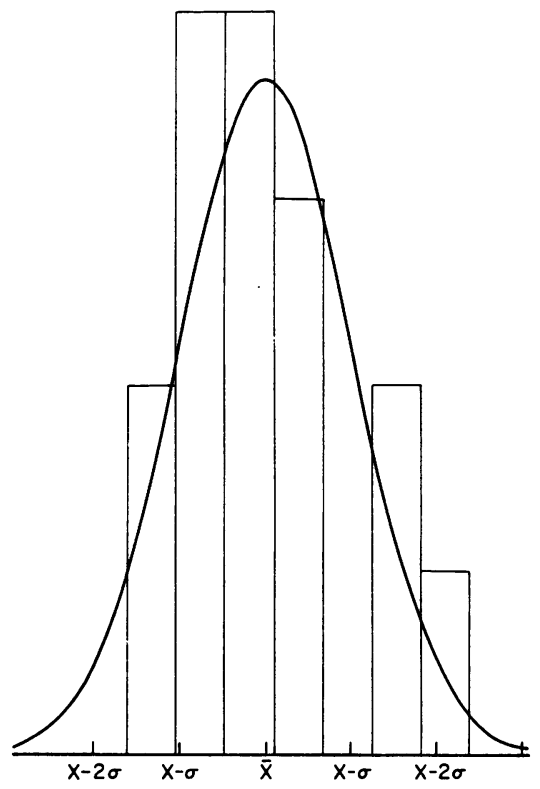

Fig. 1. Histogram and frequency distribution curve of serum zinc levels in corticosteroid-treated asthmatics ( $X=$ mean, $\sigma=1$ s.d.).

with low cardiac output syndrome treated with corticosteroids. Two years later (1973) they published similar findings in ten patients who had undergone bilateral adrenalectomy and were given substitution therapy, and in a further six patients who had been given corticosteroids for a period of between 6 months and 2 years. However, Briggs and his associates (1971) failed to find any changes in the plasma zinc levels of normal volunteers to whom 5-10 mg prednisolone had been administered for 10 days.

The present study confirms the findings of Flynn et al. $(1971 \mathrm{a} ; 1973)$ in that all the patients receiving corticosteroid therapy had lower serum zinc levels than the non-steroid-treated asthmatics. Normal zinc levels have been reported in asthmatic patients by other workers (Sinha and Gabrieli, 1970), however, in this case, it is not known whether any of these patients had been receiving corticosteroid therapy. It seems probable that the effect of corticosteroids on circulating zinc levels does not become manifest with short term administration, although Flynn et al. (1971a) reported falls of 30-75 $\mathrm{gg} 1 \mathrm{hr}$ after a single bolus of corticosteroids. The sixteen patients in the present study had all been receiving corticosteroid treatment for longer than 3 months. Patient No. 16 in fact showed a drop in serum zinc from $97 \mu \mathrm{g} / 100 \mathrm{ml}$ to $78 \mu \mathrm{g} / 100 \mathrm{ml}$ after a 3 -month period of treatment.

Plasma zinc concentrations are closely related to changes in plasma protein concentration. It is well 
recognized that the zinc in the plasma is bound to albumin (Boyett and Sullivan, 1970). All the patients studied had normal plasma protein concentrations and, in particular, there was no difference in the albumin concentrations of patients who had been treated with prednisolone and of those who had not. The changes in zinc levels cannot therefore be attributed to changes in plasma protein concentrations.

It appears that the adenohypophyseal-adrenal axis is involved in maintaining normal circulating zinc levels and in mobilizing body zinc stores (Flynn et al., 1971b; 1972). Zinc is now recognized as being an integral constituent and cofactor of several enzymes (Parisi and Vallee, 1969). The large number of zinc metallo-enzymes present in the body point to the importance of this metal in metabolism. Zinc appears to havea fundamental role in RNA, DNA and protein synthesis (Grey and Dreosti, 1972; Prasad and Oberleas, 1973; Fernandez-Madrid, Prasad and Oberleas, 1973) and is also involved in connective tissue metabolism (Fernandez-Madrid et al., 1971).

A decrease in alkaline phosphatase activity, probably due to a failure of enzyme synthesis, has long been noted in zinc deficient animals ( $\mathrm{Li}$ and Vallee, 1973). This zinc-containing metallo-enzyme is important for a number of processes in the biochemistry of normal bone formation (Bourne, 1972). Furthermore, it has been shown that radioactive zinc $\left({ }^{65} \mathrm{Zn}\right)$ is deposited at the junction of prebone and bone tissue, in the zone where calcification occurs (Haumont and McLean, 1966). It has been reported that zinc-deficient animals develop abnormalities in the epiphyseal plate region of growing bones (Westmoreland, 1971). The role of zinc in the biochemistry of bone still needs to be more precisely defined.

The authors are unable to offer a definite explanation of the clinical and biochemical significance of the decreased serum zinc levels in the corticosteroidtreated asthmatic patients. Normal body zinc stores are now believed to be essential both for normal tissue repair and for a number of enzymatic activities. It is possible that some of the side effects of long term corticosteroid therapy may, in part, be due to the depletion of zinc stores in the body. The correlation of decreased zinc levels with possible abnormal biochemical functions still remains to be made. Only a definite clinical response to zinc therapy under controlled conditions would constitute incontrovertible evidence.

\section{References}

BarbeaU, A. \& Donaldson, J. (1974) Zinc, taurine and epilepsy. Archives of Neurology, 30, 52.

BERTRAND, G. \& BHATTACHERJÉe, R.C. (1934) L'action combinée du zinc et des vitamines dans l'alimentation des animaux. Compte rendu de l'Académie des Sciences, 198, 1823.
Bourne, G.H. (1972) In: The Biochemistry and Physiology of Bone (Ed. by G. H. Bourne), p. 177. Academic Press: New York and London.

BoyeTt, J.D. \& Sullivan, J.F. (1970) Distribution of proteinf bound zinc in normal and cirrhotic serum. Metabolism, 19. 148.

Briggs, M.H., Briggs, M. \& Austin, J. (1971) Effects of steroid pharmaceuticals on plasma zinc. Nature. Londor 232, 480.

DaviES, I.J.T., MuSA, M. \& DoRmandy, T.L. (1968) Meā surements of plasma zinc. Journal of Clinical Pathology 21, 359.

Fernandez-Madrid, F., Prasad, A.S. \& Oberleas, Dọ (1971) Effect of zinc deficiency on collagen metabolism Journal of Laboratory and Clinical Medicine, 78, 853.

Fernandez-Madrid, F., Prasad, A.S. \& Oberleas, D (1973) Effect of zinc deficiency on nucleic acid, collage and non-collagenous protein of the connective tissues Journal of Laboratory and Clinical Medicine, 82, 951.

Flynn, A., Pories, W.J., Strain, W.H., Hill, O.A., JR \&. FratianNe, R.B. (1971a) Rapid serum-zinc depletiogr associated with corticosteroid therapy. Lancet, ii, 1169. ?

Flynn, A., Pories, W.J., Strain, W.H. \& Hill, O.A., JB (1971b) Mineral element correlation with adenohypo physeal-adrenal cortex function and stress. Science, $173 \vec{A}$ 1035.

Flynn, A., Pories, W.J., Strain, W.H. \& Hill, O.A., J尺 (1972) Corticotrophin, corticosteroids and zinc. (Corre spondence.) Lancet, ii, 235.

FlynN, A., Pories, W.J., Strain, W.H. \& Hill, O.A., J (1973) Zinc deficiency with altered adrenocortical functio and its relation to delayed healing. Lancet, i, 789.

GREY, P.G. \& DREOSTI, I.E. (1972) Deoxyribonucleic acid and protein metabolism in zinc deficient rats. Journalofof Comparative Pathology, 82, 223.

HALSTED, J.A. \& SMITH, J.C., JR (1970) Plasma zinc in he and disease. Lancet, $\mathbf{i}, 322$.

Haumont, S. \& MCLeAN, F.C. (1966) In: Zinc Metabolisnt (Ed. by A. S. Prasad), p. 169. Thomas: Springfield Illinois.

KeIlin, D. \& ManN, T. (1940) Carbonic anhydrase. Purifi cation and nature of the enzyme. Biochemical Journal, 34 1163.

LI, T.K. \& VAlleE, B.L. (1973) In: Modern Nutrition in Health and Disease (Ed. by R. S. Goodhart and M. E. Shills), p. 384. Lea and Febiger: Philadelphia.

Oon, B.B., Khong, K.Y., Greaves, M.W. \& Plummer, V.M:(1974) Trophic skin ulceration of leprosy: skin and serump zinc concentrations. British Medical Journal, 2, 531.

Parisi, A.F. \& VAllee, B.L. (1969) Zinc metalloenzymes characteristics and significance in biology and medicine? American Journal of Clinical Nutrition, 22, 1222.

Prasad, A.S. \& Oberleas, D. (1973) Ribonuclease and de oxyribonuclease activities in zinc-deficient tissues. Journa of Laboratory and Clinical Medicine, 82, 461.

Prasad, A.S., Oberleas, D. \& Halsted, J.A. (1966) In Zinc Metabolism (Ed. by A. S. Prasad), p. 27. Thomas Springfield, Illinois.

RAOULT, F. \& BRETON, H. (1877) Sur la présence ordinaire dư cuivre et du zinc dans le corps de l'homme. Compte rendu de l'Académie des Sciences, 85, 40.

Raulin, J. (1869) Etudes cliniques sur la végétation. Annale des Sciences Naturelles. Botanique et Biologie Végétale, 11,93.

SinHa, S.N. \& GABRIELI, E.R. (1970) Serum copper and zine levels in various pathological conditions. American Journab of Clinical Pathology, 54, 570.

Westmoreland, N. (1971) Connective tissue alternations in zinc deficiency. Federation Proceedings, 30, 1001.

WiLlis, J.B. (1962) Determination of lead and other heavy metals in urine by atomic absorption spectroscopy Analytical Chemistry, 34, 614. 